\title{
Analisa Pengaruh Pandemi Covid-19 terhadap Kinerja Keuangan Sektoral Perusahaan Emiten di Bursa Efek Indonesia
}

\author{
Budi Santoso \\ Magister Manajemen Teknologi, Institut Teknologi Sepuluh Nopember Surabaya \\ Jl. Cokroaminoto No.12A, DR. Soetomo, Kota Surabaya, Indonesia \\ budisantoso.206032@mhs.its.ac.id
}

Diterima: 09-02-2021

Disetujui: 16-06-2021

Dipublikasi: 30-06-2021

\begin{abstract}
ABSTRAK
Covid-19 yang telah menjadi pandemi diseluruh dunia membawa dampak di berbagai sektor mulai kesehatan, sosial, ekonomi, pendidikan dan beberapa sektor lainnya. Kasus Covid-19 di Indonesia pertama terdeteksi pada awal bulan Maret 2020, dan hingga bulan 18 Oktober 2020 belum ada penurunan trending jumlah kasus, dengan jumlah kasus terkonfirmasi sebesar 361.867 dan kasus aktif sebesar 64.032. Kondisi ini membawa banyak dampak salah satunya adalah pada sektor ekonomi khususnya pada kinerja keuangan perusahaan. Pada tulisan ini dilakukan analisa mengenai pengaruh covid-19 pada kinerja keuangan perusahaan yang listing di Bursa Efek Indonesia yang bergerak di beberapa sektor usaha. Pada tiap sektor akan diambil beberapa sampel dan dianalisa beberapa indicator kunci laporan keuangannya dari penjualan, laba dan rasio likuiditasnya, serta membandingkannya dengan beberapa periode waktu hingga kuartal 3 tahun 2020. Dengan adanya analisa tersebut maka dapat dijadikan pertimbangan bagi pemangku kepentingan untuk memberikan stimulasi dalam rangka percepatan pemulihan ekonomi pasca Covid-19.
\end{abstract}

Kata Kunci:

Covid-19; Laporan Keuangan; Kinerja Keuangan; Profitabilitas; Likuiditas; Bursa Efek Indonesia

\begin{abstract}
Covid-19, which has become a worldwide pandemik, has had an impact on various sectors ranging from healthcare, social, economic, education and several other sectors. The first Covid-19 cases in Indonesia were detected in early March 2020, and up to October 18, 2020 there has been no decline in the trending number of cases, with the number of confirmed cases of 361,867 and active cases of 64,032. This condition has many impacts, one of which is the economic sector, especially the company's financial performance. This paper analyzes the effect of covid-19 on the financial performance of companies listed on the Indonesia Stock Exchange that are engaged in several business sectors. In each sector several sampels will be taken and analyzed several key indicators of the financial statements from the aspects of revenue, profit and liquidity ratio, and compare them with several time periods up to the third quarter of 2020. With this analysis, it can be taken into consideration for stakeholders to provide stimulation in order to accelerate economic recovery after Covid-19.
\end{abstract}

Keywords:

Covid-19; Financial Statements; Financial Performance; Profitability; Liquidity; Indonesia Stock Exchange 


\section{PENDAHULUAN}

Pendemi virus korona atau yang umum dikenal sebagai Covid-19 pertama kali muncul di kota Wuhan China pada akhir tahun 2019, kemudian menyebar dengan cepat ke seluruh dunia. Kasus Covid19 terkonfirmasi muncul pertama kali di Indonesia pada 2 Maret 2020 sebanyak 2 kasus. Pada 18 oktober 2020 jumlah kasus terkonfirmasi sebesar 361.867 dan kasus aktif sebesar 64.032 dan belum ada trending penurunan jumlah kasus perhari (Satgas Covid-19, 2020).

Dalam rangka pencegahan penyebaran covid ini berbagai upaya mitigasi resiko telah dilakukan antara lain pemberlakuan Pembatasan Sosial Berskala Besar (PSBB) yang telah diterapkan pada beberapa provinsi pada beberapa periode yang lalu. Pemberlakuan PSBB ini bertujuan membatasi aktivitas sosial masyarakat dengan action plan seperti penutupan mall, pasar, sekolah, jalur kereta, ataupun penutupan sementara jalur transportasi umum. Sebagian besar perusahaan dan bidang usaha pun memberlakukan skenario untuk pencegahan covid antara lain bekerja dari rumah (work from home / WFH) baik Sebagian maupun seluruh karyawan. Pada sektor pendidikan dilakukan penghentian proses belajar mengajar secara tatap muka dan diganti dengan pembelajaran secara daring (dalam jaringan) atau pembelajaran online. Hal ini berlaku mulai dari jenjang pendidikan pra-sekolah hingga perguruan tinggi. Pemberlakukan protokol kesehatan dilakukan secara ketat antara lain wajib menggunakan masker, menjaga jarak dan sering cuci tangan dengan sanksi denda ataupun kerja sosial bagi pelanggarnya. Terjadinya pandemi corona ini membawa dampak serius di berbagai sektor seperti bidang kesehatan, ekonomi, transportasi dan bidang industri lainnya. Mobilitas orang pun menurun sangat drastis dengan adanya pembatasan PSBB, lockdown, karantina wilayah dan sejenisnya. Okupasi hotel, tempat-tempat rekreasi, mall, transportasi umum baik darat, laut maupun udara pun menurun secara signifikan. Hal ini membawa dampak yang luas secara perekonomian.

Permasalahan yang diteliti pada paper ini adalah:

1. Sejauh mana pengaruh covid tersebut pada kinerja keuangan perusahaan-perusahaan yang terdaftar dalam bursa efek Indonesia,

2. Bagaimana rata-rata pengaruh pandemik Covid-19 pada performa kinerja keuangan perusahaan-perusahaan di semua sektor usaha.

3. Bagaimana signifikansi pengaruh Covid-19 pada kinerja keuangan masing-masing sektor, sektor-sektor apa saja yang terdampak sangat signifikan, moderat, ringan bahkan mengalami kenaikan kinerja.

Tujuan penulisan paper ini adalah untuk menganalisa laporan keuangan beberapa perusahaan yang terdaftar pada Bursa Efek Indonesia sebagai dampak adanya pandemik Covid 19 ini.

Berbagai studi telah meneliti dampak terjadinya pandemi Covid-19 pada performa perusahaan. China sebagai negara pertama yang terimbas oleh pandemi mendapatkan dampak negatif yang signifikan terhadap kinerja perusahaan-perusahaan terdaftar di bursa China dengan menurunnya skala investasi dan berkurangnya total pendapatan. Untuk industri yang terkena pandemi seperti pariwisata, catering/restoran, dan transportasi, terdapat penurunan kinerja perusahaan yang cukup signifikan pada 
triwulan I tahun 2020. Pandemi tersebut berdampak negatif terhadap produksi, operasi, dan penjualan industri tersebut, yang akhirnya tercermin dalam tingkat keuntungan yang negatif. Dampak negatif jauh lebih terasa di daerah yang terkena karantina karena terjadi pembatasan yang ketat dalam konsumsi dan produksi. Kondisi ini mempersulit keuangan perusahaan yang membuat manajemen operasi semakin sulit. (Shen, 2020).

Pandemi virus corona dapat berdampak signifikan terhadap laporan keuangan tahun 2020 terutama dalam beberapa aspek berikut: (a). Pendapatan perusahaan yang akan menurun akibat daya beli masyarakat yang melemah dan kemungkinan terjadinya inflasi. (b). Pengaruh rantai pasokan (supply chain) perusahaan terutama yang mendapatkan bahan baku dari China yang dapat meningkatkan harga pokok penjualan. (d). Kesulitan likuiditas salah satunya akibat kerugian karena keusangan barang persediaan atau kerusakan bahan baku yang melewati masa kadaluarsa. (e) Pengaruh kurs pada laporan keuangan terutama bila perusahaan memiliki utang/piutang dalam mata uang dollar dan tidak melakukan lindung nilai. (f) Laba perusahaan mungkin akan menurun pada tahun 2020 akibat pandemi corona. (CAS-FEB-UNPAD, 2020).

Potensi dampak Covid-19 ini meliputi dampak langsung jangka pendek hingga efek jangka panjang dan tidak langsung (Koster \& Igoe, 2020). Seperti ilustrasi yang ditampilkan pada gambar 1 berikut, adanya pembatasan yang ketat pada kegiatan masyarakat dan perekonomian memberikan pengaruh penurunan permintaan dan kemampuan menjalankan bisnis. Penurunan permintaan masyarakat diakibatkan oleh menurunan daya beli masyarakat karena menurunnya perekonomian membawa dampak langsung pada besarnya penjualan (sales and revenue) perusahaan. Hal tersebut memberikan dampak langsung pada aspek profitabilitas, likuiditas, kualitas hutang, tenaga kerja dan supply chain.

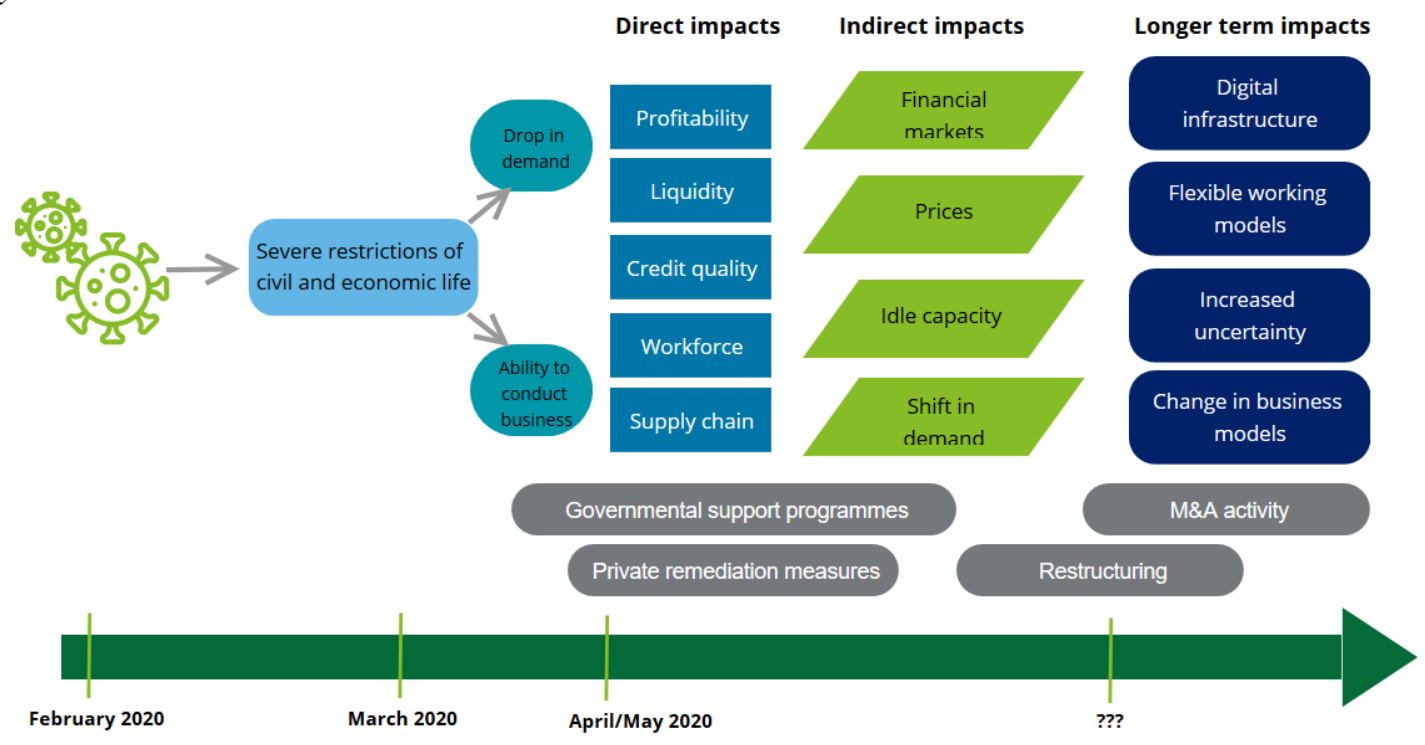

Gambar 1. Potensi dampak Covid-19.

Sumber: (Koster \& Igoe, 2020) 
Dampak tidak langsungnya adalah terpengaruhnya aspek keuangan pasar, harga, idle capacity karena permintaan menurun dan pergeseran permintaan. Analisa kondisi keuangan perusahaan dapat dilakukan dengan menggunakan beberapa laporan keuangan. Laporan keuangan terdiri dari: (a). Neraca (balance sheet) yang merangkum aset, kewajiban (liabilities), kondisi modal (equity) pemilik bisnis pada waktu tertentu, biasanya akhir tahun atau triwulan. (b) Laporan laba rugi (income statement) melaporkan rangkuman pendapatan dan biaya-biaya sebuah perusahaan dalam waktu tertentu, biasanya akhir tahun ataupun triwulan. Neraca mewakili potret posisi keuangan perusahaan pada suatu waktu, sedangkan laporan laba rugi menggambarkan rangkuman profitability perusahaan dari waktu ke waktu (Van Horne \& John M. Wachowicz, Jr, 2009).

Rasio keuangan berfungsi sebagai alat yang digunakan untuk menilai kondisi keuangan dan kinerja perusahaan, yang akan memberikan informasi berharga tentang kesehatan perusahaan, kondisi keuangan dan profitabilitasnya. Alat yang sering digunakan selama pemeriksaan ini adalah rasio keuangan, atau indeks, yang menghubungkan dua bagian data keuangan dengan membagi satu kuantitas dengan kuantitas lainnya. (Van Horne \& John M. Wachowicz, Jr, 2009)

Analisis rasio keuangan dapat diinterpretasikan dengan membuat dua jenis perbandingan. (1) Perbandingan Internal, yakni membandingkan rasio sekarang dengan rasio masa lalu maupun prediksi rasio yang akan datang untuk perusahaan yang sama. Hal ini dilakukan untuk mempelajari komposisi perubahan dan menentukan apakah telah terjadi peningkatan atau penurunan kondisi keuangan dan kinerja perusahaan dari waktu ke waktu. (2) Perbandingan Eksternal dengan industri sejenis. Metode perbandingan kedua adalah dengan membandingkan rasio satu perusahaan dengan perusahaan serupa atau dengan rata-rata industri pada titik waktu yang sama. Perbandingan tersebut memberikan informasi tentang kondisi keuangan relatif dan kinerja perusahaan (Van Horne \& John M. Wachowicz, Jr, 2009).

\section{METODE RISET}

Metode yang digunakan pada paper ini adalah dengan menganalisa data laporan keuangan perusahaan-perusahaan yang terdaftar pada Bursa Efek Indonesia. Data didapatkan dari laporan keuangan resmi yang dipublikasikan oleh setiap perusahaan yang terdaftar pada bursa pasar modal yang terdiri dari laporan tahunan yang dilaporkan setiap akhir tahun (31 Desember) maupun laporan kuartal yang dilaporkan tiap periode triwulanan, terdiri dari TW1 (31 Maret), TW2 (30 Juni), TW3 (30 September). Data laporan keuangan didapatkan dari laman resmi Bursa Efek Indonesia (Indonesian Stock Exchange - IDX) yakni https://www.idx.co.id/ perusahaan-tercatat/laporan-keuangan-dantahunan/. (IDX, 2020). Pengambilan sampel perusahaan dilakukan sehingga terdapat perwakilan masing-masing sektor bidang usaha sesuai jenis sektor pada Bursa Efek Indonesia yang terdiri dari (1) Agriculture, (2) Basic Industry and Chemicals, (3) Costumer Goods Industry, (4) Finance, (5) Infrastructure, utilities and Transportation, (6) Mining, (7) Property, Real Estate and Building Construction, (8) Trade, Service and Investment dan (9) Miscellaneous Industry. 
Parameter yang dianalisa pada laporan keuangan antara lain penjualan, laba, dan rasio likuiditas, yang kemudian dilakukan analisa perbandingan antar satu periode dengan periode lainnya. Periode yang akan dianalisa meliputi tahun 2018-2019 sebelum terjadinya Covid-19, serta kuartal 1-3 tahun 2020 setelah terjadinya Covid-19. Dengan demikian masing-masing sampel perusahaan membutuhkan 7 laporan keuangan yang dianalisa, yakni Laporan Keuangan TW1 2019, Laporan Keuangan TW2 2019, Laporan Keuangan TW3 2019, Laporan Keuangan Tahunan 2019, Laporan Keuangan TW1 2020, Laporan Keuangan TW2 2020 dan Laporan Keuangan TW3 2020.

\section{HASIL PENELITIAN DAN PEMBAHASAN}

Berikut ini adalah data statistik dekriptif yang didapatkan dari laporan keuangan masingmasing sampel perusahaan yang diambil untuk tiap-tiap kategori sektor industri. Data yang diambil adalah laporan keuangan tahunan 2019 yang mewakili kondisi sebelum terjadinya pandemik virus corona, serta data laporan keuangan Kuartal 1 tahun 2020 yang merupakan periode awal terjadinya pandemik Covid-19, serta Kuartal 2 dan Kuartal 3 tahun 2020 yang mencerminkan periode-periode berikutnya sebagai efek terjadinya pandemik Covid-19. Setiap laporan keuangan dibandingkan dengan laporan pada periode yang sama dari tahun sebelumnya sehingga didapatkan data prosentase pertumbuhan dari tahun ke tahun.

\section{Sampel Data Perusahaan}

Dari masing-masing sektor diambil sejumlah sampel perusahaan sedemikian rupa sehingga dapat menggambarkan kondisi masing-masing sektor tersebut. Daftar sampel perusahaan dapat dilihat pada tabel 1 berikut ini:

Tabel 1. Data sampel perusahaan

\begin{tabular}{lc}
\hline \multicolumn{1}{c}{ Sektor } & $\begin{array}{c}\text { Jumlah sampel } \\
\text { perusahaan }\end{array}$ \\
\hline (1) Agriculture & 11 \\
(2) Basic Industry and Chemicals & 10 \\
(3) Costumer Goods Industry & 12 \\
(4) Finance & 11 \\
(5) Infrastructure, utilities and Transportation & 7 \\
(6) Mining & 10 \\
(7) Property, Real Estate and Building Construction & 7 \\
(8) Trade, Service and Investment & 11 \\
(9) Miscellaneous Industry & 8 \\
\hline Semua industri & 87 \\
\hline \multicolumn{2}{c}{ Sumber: Analisa data penulis }
\end{tabular}

\section{Pertumbuhan Pendapatan (Sales \& Revenue) dari tahun ke tahun (year to year)}

Adanya pandemik dengan berbagai pembatasan aktivitas masyarakat berdampak langsung terhadap besarnya penjualan atau pendapatan perusahaan. Data variabel pertumbuhan pendapatan dari tahun ke tahun (year-to-year) masing-masing sektor industri dapat ditunjukkan pada Tabel 2. 
Tabel 2. Data Pertunbuhan Pendapatan year-to-year perusahaan masing-masing sektor industri

\begin{tabular}{|c|c|c|c|c|c|}
\hline \multicolumn{2}{|c|}{ Sektor $(*)$} & EOY-19 & TW1-20 & TW2-20 & TW3-20 \\
\hline \multirow[t]{5}{*}{ (1) } & Mean & $-3,02 \%$ & $9,65 \%$ & $14,03 \%$ & $12,38 \%$ \\
\hline & std dev & $10,13 \%$ & $18,63 \%$ & $18,23 \%$ & $27,17 \%$ \\
\hline & Min & $-18,51 \%$ & $-27,61 \%$ & $-9,81 \%$ & $-11,93 \%$ \\
\hline & Max & $20,47 \%$ & $35,03 \%$ & $57,24 \%$ & $85,42 \%$ \\
\hline & $\mathrm{N}$ & 11 & 11 & 11 & 11 \\
\hline \multirow[t]{5}{*}{ (2) } & Mean & $0,55 \%$ & $-15,05 \%$ & $-18,31 \%$ & $-16,54 \%$ \\
\hline & std dev & $16,16 \%$ & $31,53 \%$ & $29,36 \%$ & $29,50 \%$ \\
\hline & Min & $-21,89 \%$ & $-99,89 \%$ & $-99,90 \%$ & $-99,91 \%$ \\
\hline & Max & $31,55 \%$ & $6,01 \%$ & $0,00 \%$ & $-1,40 \%$ \\
\hline & $\mathrm{N}$ & 10 & 10 & 10 & 10 \\
\hline \multirow[t]{5}{*}{ (3) } & Mean & $-0,03 \%$ & $2,59 \%$ & $-4,20 \%$ & $-3,81 \%$ \\
\hline & std dev & $25,53 \%$ & $10,72 \%$ & $15,29 \%$ & $15,10 \%$ \\
\hline & Min & $-79,68 \%$ & $-17,64 \%$ & $-48,65 \%$ & $-47,59 \%$ \\
\hline & Max & $15,48 \%$ & $24,18 \%$ & $8,75 \%$ & $11,70 \%$ \\
\hline & $\mathrm{N}$ & 12 & 12 & 12 & 12 \\
\hline \multirow[t]{5}{*}{ (4) } & Mean & $11,08 \%$ & $8,50 \%$ & $2,63 \%$ & $-4,58 \%$ \\
\hline & std dev & $8,82 \%$ & $24,87 \%$ & $22,14 \%$ & $17,02 \%$ \\
\hline & Min & $-1,73 \%$ & $-45,04 \%$ & $-38,81 \%$ & $-41,26 \%$ \\
\hline & Max & $34,93 \%$ & $62,53 \%$ & $56,69 \%$ & $21,52 \%$ \\
\hline & $\mathrm{N}$ & 11 & 11 & 11 & 11 \\
\hline \multirow[t]{5}{*}{ (5) } & Mean & $5,27 \%$ & $-0,91 \%$ & $-5,88 \%$ & $-6,70 \%$ \\
\hline & std dev & $5,17 \%$ & $12,70 \%$ & $16,58 \%$ & $16,93 \%$ \\
\hline & Min & $-0,56 \%$ & $-24,29 \%$ & $-29,44 \%$ & $-26,16 \%$ \\
\hline & Max & $12,87 \%$ & $11,57 \%$ & $13,17 \%$ & $13,49 \%$ \\
\hline & $\mathrm{N}$ & 7 & 7 & 7 & 7 \\
\hline \multirow[t]{5}{*}{ (6) } & Mean & $15,33 \%$ & $-0,26 \%$ & $-12,86 \%$ & $-18,14 \%$ \\
\hline & std dev & $35,20 \%$ & $16,90 \%$ & $15,12 \%$ & $11,91 \%$ \\
\hline & Min & $-17,01 \%$ & $-19,23 \%$ & $-36,05 \%$ & $-33,18 \%$ \\
\hline & Max & $101,70 \%$ & $33,64 \%$ & $16,36 \%$ & $4,21 \%$ \\
\hline & $\mathrm{N}$ & 10 & 10 & 10 & 10 \\
\hline \multirow[t]{5}{*}{ (7) } & Mean & $47,35 \%$ & $113,52 \%$ & $154,09 \%$ & $-5,71 \%$ \\
\hline & std dev & $114,77 \%$ & $293,11 \%$ & $429,86 \%$ & $13,21 \%$ \\
\hline & Min & $-2,22 \%$ & $-8,31 \%$ & $-35,09 \%$ & $-26,09 \%$ \\
\hline & Max & $307,47 \%$ & $777,43 \%$ & $1128,28 \%$ & $11,34 \%$ \\
\hline & $\mathrm{N}$ & 7 & 7 & 7 & 7 \\
\hline \multirow[t]{5}{*}{ (8) } & Mean & $17,58 \%$ & $11,13 \%$ & $-1,86 \%$ & $-3,71 \%$ \\
\hline & std dev & $28,10 \%$ & $36,94 \%$ & $44,07 \%$ & $38,17 \%$ \\
\hline & Min & $-5,42 \%$ & $-19,04 \%$ & $-32,19 \%$ & $-34,01 \%$ \\
\hline & Max & $98,63 \%$ & $118,33 \%$ & $125,78 \%$ & $102,83 \%$ \\
\hline & $\mathrm{N}$ & 11 & 11 & 11 & 11 \\
\hline \multirow[t]{5}{*}{ (9) } & Mean & $-16,01 \%$ & $-7,04 \%$ & $-21,79 \%$ & $-19,63 \%$ \\
\hline & std dev & $37,56 \%$ & $10,94 \%$ & $8,81 \%$ & $9,21 \%$ \\
\hline & Min & $-79,32 \%$ & $-31,63 \%$ & $-33,41 \%$ & $-27,40 \%$ \\
\hline & Max & $14,30 \%$ & $1,94 \%$ & $-3,71 \%$ & $1,34 \%$ \\
\hline & $\mathrm{N}$ & 8 & 8 & 8 & 8 \\
\hline
\end{tabular}


Santoso, B. (2021). Analisa Pengaruh Pandemi Covid-19 terhadap ....

\begin{tabular}{llllll}
\hline Sektor (*) & \multicolumn{1}{c}{ EOY-19 } & TW1-20 & TW2-20 & TW3-20 \\
\hline $\mathbf{( 1 0 )}$ & Mean & $7,94 \%$ & $11,76 \%$ & $8,96 \%$ & $-6,36 \%$ \\
& std dev & $40,95 \%$ & $87,61 \%$ & $126,11 \%$ & $23,79 \%$ \\
Min & $-79,68 \%$ & $-99,89 \%$ & $-99,90 \%$ & $-99,91 \%$ \\
Max & $307,47 \%$ & $777,43 \%$ & $1128,28 \%$ & $102,83 \%$ \\
$\mathrm{~N}$ & 87 & 87 & 87 & 87 \\
\hline \multicolumn{5}{c}{ Sumber:Analisa data penulis }
\end{tabular}

(*)Keterangan Sektor: (1) Agriculture, (2) Basic Industry and Chemicals, (3) Costumer Goods Industry, (4) Finance, (5) Infrastructure, utilities and Transportation, (6) Mining, (7) Property, Real Estate and Building Construction (8) Trade, Service and Investment, (9) Miscellaneous Industry). (10) Resume data semua sampel yang diambil untuk semua kategori sektor industri.

Berdasarkan data tersebut pada tabel 2 di atas, adanya Covid-19 mengakibatkan turunnya ratarata penjualan hampir di semua sektor industri, efek tersebut mulai terlihat pada kuartal 2 dan kuartal 3 tahun 2020. Namun demikian terdapat sektor-sektor tertentu yang mengalami peningkatan penjualan yang cukup besar yakni sektor Agriculture dan sektor Property, Real Estate and Building Construction. Kenaikan pada kedua sektor tersebut membawa dampak rata-rata pertumbuhan penjualan semua sektor industri justru naik pada TW1 dan TW2 tahun 2020 sebesar 11,76\% dan 8,96\%. Sementara pada TW3 tahun 2020 tingkat rata-rata penjualan semua sektor industri turun 6,36\% dibanding TW3 tahun 2019.

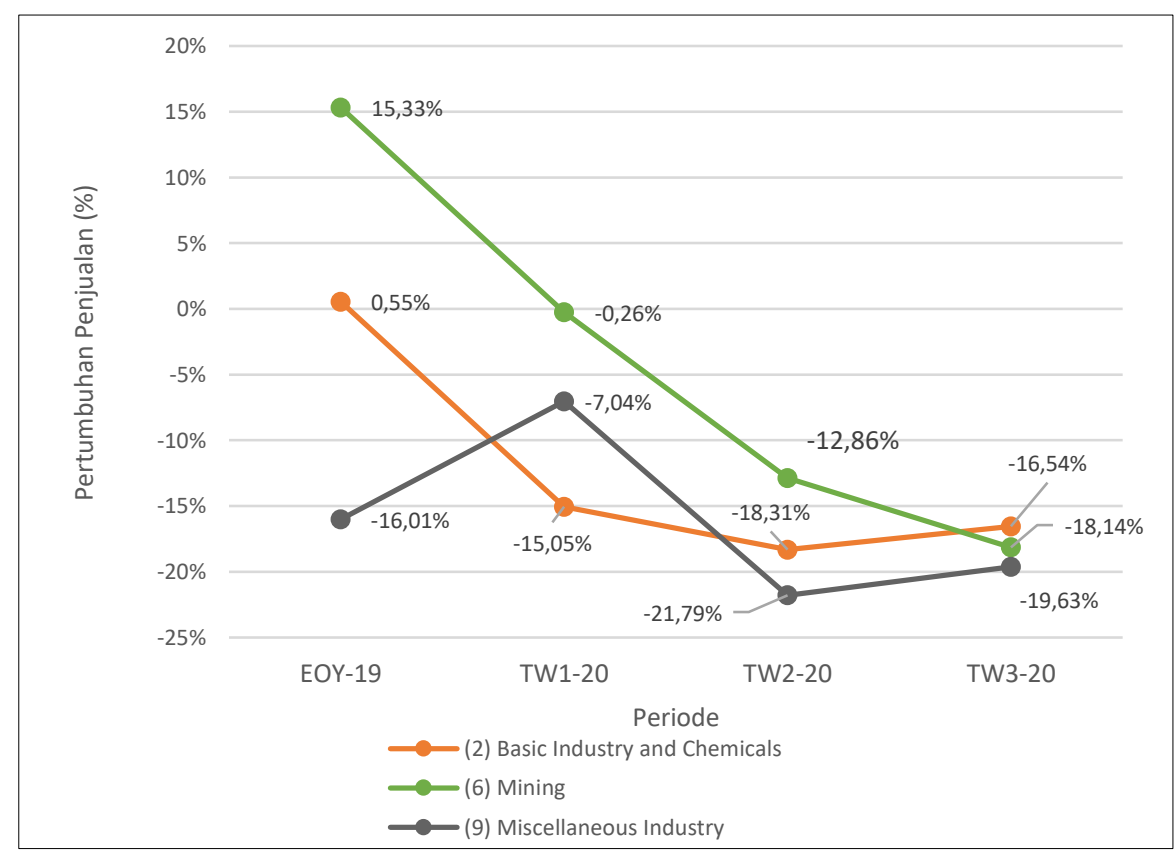

Gambar 2. Grafik perubahan penjualan sektor Basic Industri and Chemicals, Mining, Miscelenous Industry

Sumber: Analisa data penulis

\section{Terdampak Berat}

Sektor industri yang mengalami tingkat dampak penurunan pendapatan pada 3 peringkat terbesar antara lain sektor (a) Miscellaneous Industry, (b) Basic Industry and Chemicals, dan (c) Mining, mengalami penurunan penjualan lebih dari $10 \%$ hingga $22 \%$. 


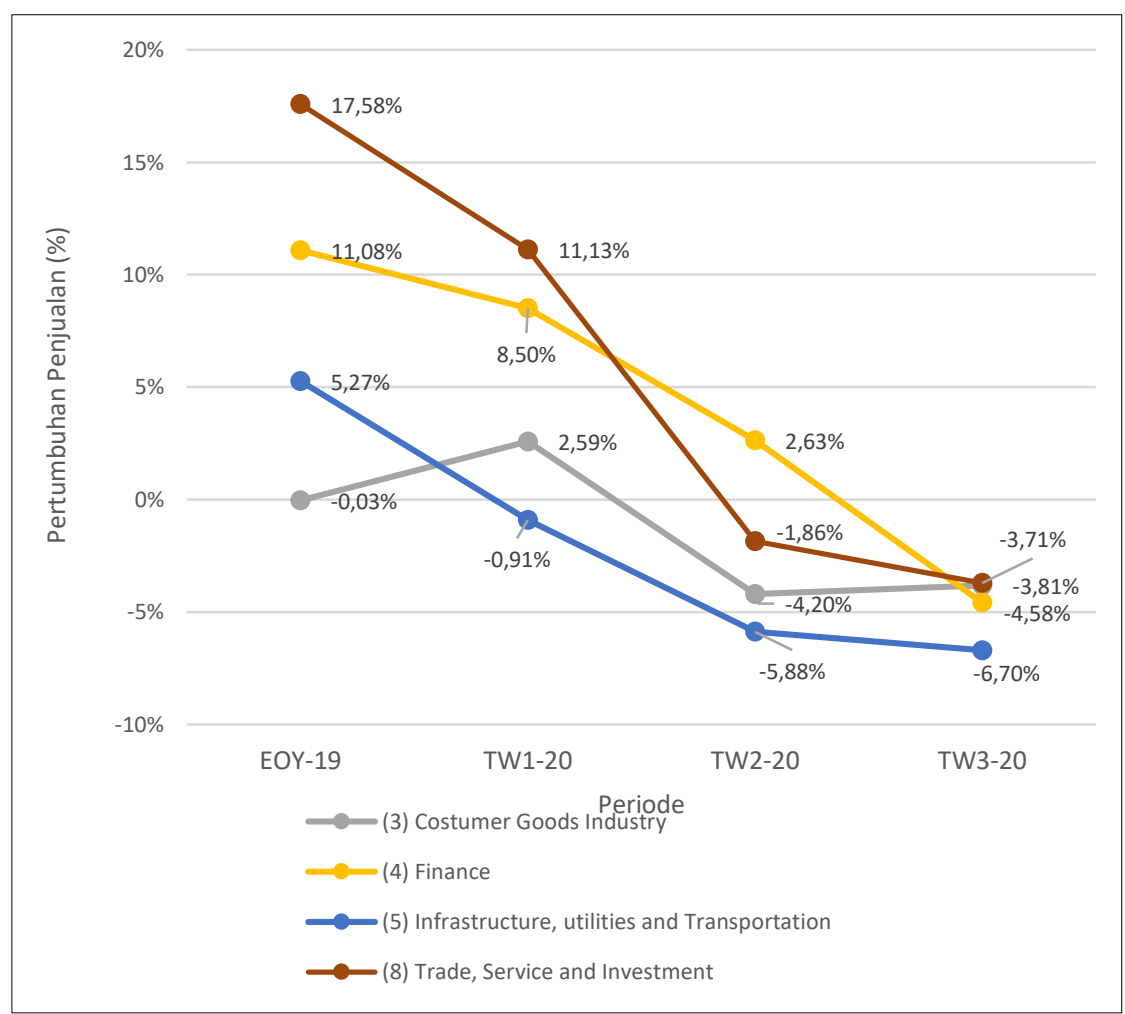

Gambar 3. Grafik perubahan penjualan sektor (3) Customer Goods Industry, (4) Finance, (5) Infrastructure, (8) Utilities and Transportation, Trade, Service and Investment

Seperti ditunjukkan pada gambar 2 di atas, sektor Mining pada kuartal 2 tahun 2020 mengalami penurunan tingkat penjualan sebesar 12,86\% dan kuartal 3 tahun 2020 mengalami penurunan sebesar 18,14\%. Tingkat Penjualan Sektor Miscellaneous Industry pada kuartal 2 dan kuartal 3 tahun 2020 menurun berturut-turut sebesar 21,79\% dan 19,63\%. Sedangkan sektor Basic Industry and Chemicals tingkat penjualannya menurun pada kuartal 2 dan kuartal 3 sebesar 18,31\% dan 18,14\%.

\section{Terdampak Menengah}

Penurunan tingkat penjualan antara 1\% hingga 7\% pada TW1 dan TW 2 tahun 2020, antara lain terjadi pada sektor (5) Infrastructure, utilities and Transportation, (3) Costumer Goods Industry, (8) Trade, Service and Investment, dan (4) Finance. Grafik pada Gambar 3 di atas menunjukkan prosentase perubahan penjualan tahun ke tahun keempat sektor tersebut.

Sektor Infrastructure, utilities and Transportation, mengalami penurunan rata-rata tingkat penjualan sejak TW1 2020 sebesar -0,91\%, dan pada TW2 dan TW3 tahun 2020 berturut-turut turun sebesar 5,88\% dan 6,7\%. Sektor Costumer Goods Industry mengalami penurunan rata-rata penjualan pada TW2 dan TW3 tahun 2020 sebesar 4,2\% dan 3,81\%, sedangkan sektor Trade, Service and Investment mengalami penurunan pada TW2 dan TW3 tahun 2020 berturut-turut sebesar 1,86\% dan 3,71\%. Sektor Finance mengalami penurunan rata-rata penjualan pada TW3 2020 sebesar 4,58\%. 
Tidak Terdampak/ terdampak Rendah

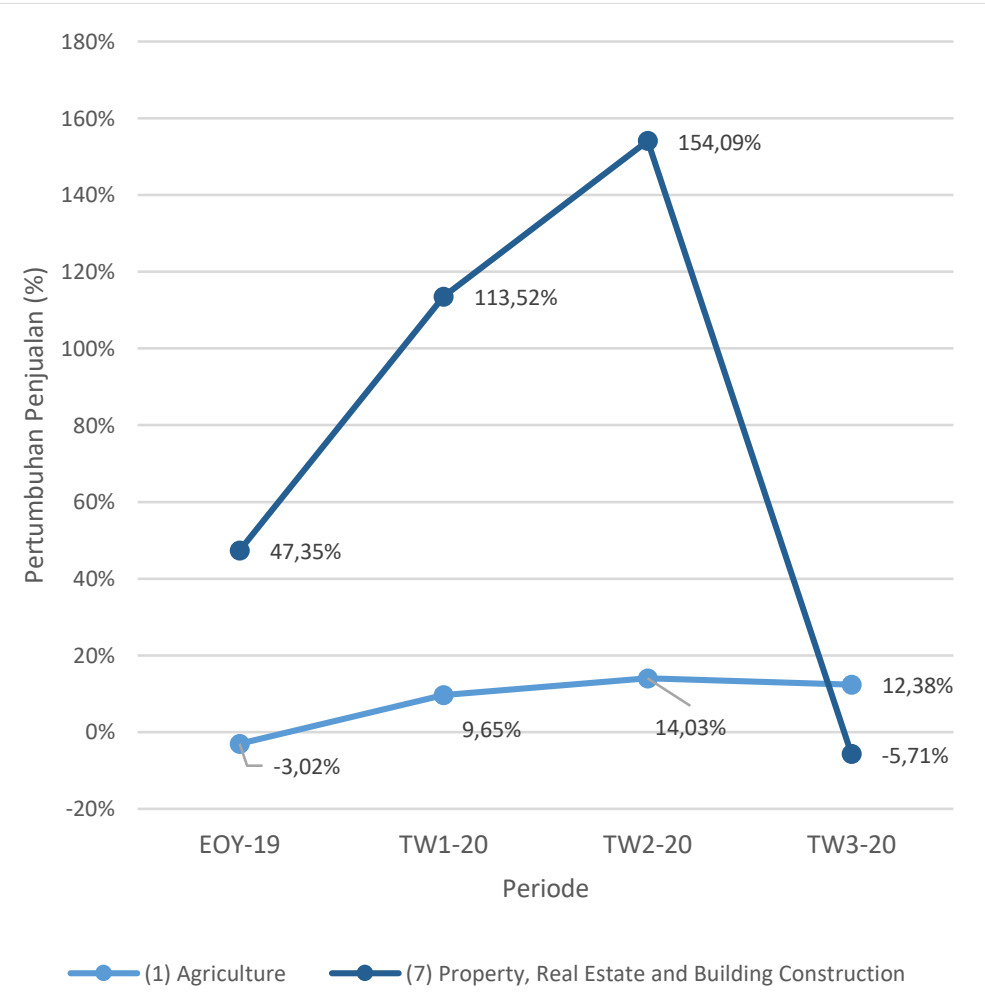

Gambar 4. Grafik perubahan penjualan sektor (1) Agriculture dan (7) Property, Real Estate and Building Construction Sumber:analisa data penulis

Sektor agriculture tidak mengalami dampak penurunan rata-rata penjualan seperti terlihat pada gambar 4, dimana pada TW1-TW3 tahun 2020 justru mengalami kenaikan rata-rata penjualan berturutturut sebesar 9,65\%, 14,03\% dan 12,38\%. Sektor Property, Real Estate and Building Construction pada TW 1 dan TW 2 tahun 2020 mengalami kenaikan penjualan cukup besar yakni 113,52\% dan 154,09\%, tetapi pada TW3 2020 penjualannya menurun 5,71\% dibanding periode yang sama tahun sebelumnya

\section{Pertumbuhan Laba (Profit for the period) dari tahun ke tahun (year to year)}

Berikut ini adalah data variabel pertumbuhan laba / profit for the periode (year-to-year) dapat ditampilkan pada Tabel 3 berikut ini.

Tabel 3 Data Pertumbuhan Laba year-to-year masing-masing sektor industri.

\begin{tabular}{llllll}
\hline Sektor(*) & EOY-19 & TW1-20 & TW2-20 & TW3-20 \\
\hline (1) & Mean & $-156,08 \%$ & $-531,07 \%$ & $-653,99 \%$ & $42,91 \%$ \\
& std dev & $241,04 \%$ & $1882,62 \%$ & $2477,48 \%$ & $250,88 \%$ \\
& Min & $-827,19 \%$ & $-6125,04 \%$ & $-7989,88 \%$ & $-466,54 \%$ \\
& Max & $50,34 \%$ & $859,33 \%$ & $853,85 \%$ & $437,83 \%$ \\
& N & 11 & 11 & 11 & 11 \\
\hline $\mathbf{( 2 )}$ & Mean & $-17,82 \%$ & $18,01 \%$ & $-13,07 \%$ & $-0,09 \%$ \\
& std dev & $90,55 \%$ & $124,48 \%$ & $79,25 \%$ & $96,61 \%$ \\
& Min & $-201,67 \%$ & $-177,33 \%$ & $-99,87 \%$ & $-99,88 \%$ \\
\hline
\end{tabular}




\begin{tabular}{|c|c|c|c|c|c|}
\hline \multicolumn{2}{|c|}{ Sektor(*) } & \multirow{2}{*}{$\begin{array}{c}\text { EOY-19 } \\
160,27 \%\end{array}$} & \multirow{2}{*}{$\begin{array}{c}\text { TW1-20 } \\
225,32 \%\end{array}$} & \multirow{2}{*}{$\begin{array}{l}\text { TW2-20 } \\
129,47 \%\end{array}$} & \multirow{2}{*}{$\frac{\text { TW3-20 }}{226,94 \%}$} \\
\hline & Max & & & & \\
\hline & $\mathrm{N}$ & 10 & 10 & 10 & 10 \\
\hline \multirow[t]{5}{*}{ (3) } & Mean & $10,81 \%$ & $14,17 \%$ & $-9,41 \%$ & $-8,90 \%$ \\
\hline & std dev & $23,26 \%$ & $36,99 \%$ & $34,12 \%$ & $33,87 \%$ \\
\hline & Min & $-35,81 \%$ & $-41,60 \%$ & $-87,01 \%$ & $-79,81 \%$ \\
\hline & Max & $47,64 \%$ & $97,85 \%$ & $31,39 \%$ & $40,82 \%$ \\
\hline & $\mathrm{N}$ & 12 & 12 & 12 & 12 \\
\hline \multirow[t]{5}{*}{ (4) } & Mean & $10,16 \%$ & $-4,98 \%$ & $-32,62 \%$ & $-100,16 \%$ \\
\hline & std dev & $39,25 \%$ & $41,39 \%$ & $26,11 \%$ & $236,16 \%$ \\
\hline & Min & $-92,55 \%$ & $-99,54 \%$ & $-54,95 \%$ & $-803,65 \%$ \\
\hline & Max & $66,48 \%$ & $39,49 \%$ & $32,60 \%$ & $39,72 \%$ \\
\hline & $\mathrm{N}$ & 11 & 11 & 11 & 11 \\
\hline \multirow[t]{5}{*}{ (5) } & Mean & $43,10 \%$ & $322,26 \%$ & $52,38 \%$ & $14,94 \%$ \\
\hline & std dev & $82,44 \%$ & $986,48 \%$ & $209,09 \%$ & $137,58 \%$ \\
\hline & Min & $-69,02 \%$ & $-111,41 \%$ & $-84,43 \%$ & $-79,80 \%$ \\
\hline & Max & $178,19 \%$ & $2557,16 \%$ & $517,40 \%$ & $316,32 \%$ \\
\hline & $\mathrm{N}$ & 7 & 7 & 7 & 7 \\
\hline \multirow[t]{5}{*}{ (6) } & Mean & $82,19 \%$ & $-73,83 \%$ & $-75,72 \%$ & $-101,29 \%$ \\
\hline & std dev & $338,12 \%$ & $91,48 \%$ & $109,81 \%$ & $182,68 \%$ \\
\hline & Min & $-77,83 \%$ & $-264,18 \%$ & $-355,45 \%$ & $-546,89 \%$ \\
\hline & Max & $1038,43 \%$ & $55,11 \%$ & $50,36 \%$ & $40,54 \%$ \\
\hline & $\mathrm{N}$ & 10 & 10 & 10 & 10 \\
\hline \multirow[t]{5}{*}{$\begin{array}{l}(7) \\
\end{array}$} & Mean & $21,42 \%$ & $-245,89 \%$ & $-23,37 \%$ & $-38,36 \%$ \\
\hline & std dev & $129,27 \%$ & $624,10 \%$ & $86,76 \%$ & $81,06 \%$ \\
\hline & Min & $-223,98 \%$ & $-1644,55 \%$ & $-100,69 \%$ & $-95,58 \%$ \\
\hline & Max & $174,65 \%$ & $195,15 \%$ & $141,01 \%$ & $137,76 \%$ \\
\hline & $\mathrm{N}$ & 7 & 7 & 7 & 7 \\
\hline \multirow[t]{5}{*}{ (8) } & Mean & $23,13 \%$ & $-139,84 \%$ & $-279,04 \%$ & $-483,69 \%$ \\
\hline & std dev & $54,90 \%$ & $341,14 \%$ & $791,82 \%$ & $1493,08 \%$ \\
\hline & Min & $-87,40 \%$ & $-1137,47 \%$ & $-2657,92 \%$ & $-4980,22 \%$ \\
\hline & Max & $105,65 \%$ & $73,99 \%$ & $65,51 \%$ & $112,64 \%$ \\
\hline & $\mathrm{N}$ & 11 & 11 & 11 & 11 \\
\hline \multirow[t]{5}{*}{$\begin{array}{l}(9) \\
\end{array}$} & Mean & $16,43 \%$ & $14,42 \%$ & $-57,80 \%$ & $-35,53 \%$ \\
\hline & std dev & $224,52 \%$ & $193,80 \%$ & $104,30 \%$ & $115,44 \%$ \\
\hline & Min & $-363,78 \%$ & $-339,22 \%$ & $-224,73 \%$ & $-174,96 \%$ \\
\hline & Max & $460,94 \%$ & $359,35 \%$ & $78,23 \%$ & $196,47 \%$ \\
\hline & $\mathrm{N}$ & 8 & 8 & 8 & 8 \\
\hline \multirow[t]{5}{*}{ (10) } & Mean & $-1,14 \%$ & $-87,51 \%$ & $-140,99 \%$ & $-91,00 \%$ \\
\hline & std dev & $176,59 \%$ & $769,71 \%$ & $932,75 \%$ & $561,97 \%$ \\
\hline & Min & $-827,19 \%$ & $-6125,04 \%$ & $-7989,88 \%$ & $-4980,22 \%$ \\
\hline & Max & $1038,43 \%$ & $2557,16 \%$ & $853,85 \%$ & $437,83 \%$ \\
\hline & $\mathrm{N}$ & 87 & 87 & 87 & 87 \\
\hline
\end{tabular}

Sumber:analisa data penulis

(*) Keterangan Sektor (1) Agriculture, (2) Basic Industry and Chemicals, (3) Costumer Goods Industry, (4) Finance, (5) Infrastructure, utilities and Transportation, (6) Mining, (7) Property, Real Estate and Building Construction (8) Trade, Service and Investment, (9) Miscellaneous Industry). (10) Resume data semua sampel yang diambil untuk semua kategori sektor industri 
Naik turunnya besaran laba (profit of the period) ditentukan oleh volume penjualan, harga pokok produksi (cost of goods sells) dan biaya beban administrasi serta beban penjualan.

Secara rata-rata industri dari data sampel yang diambil, besarnya laba perusahaan pada kuartal

1 hingga kuartal 3 tahun 2020 mengalami penurunan yang sangat besar berturut-turut sebesar 87,51\%, $140,99 \%$, dan $91,00 \%$ dibanding periode yang sama tahun sebelumnya. Tingkat perubahan laba ini memiliki standar deviasi yang cukup besar yakni pada kwartal 1, 2, dan 3 berturut-turut 769,71\%, $932,75 \%, 561,97 \%$ yang artinya ada sektor-sektor perusahaan yang justru mengalami peningkatan laba dan demikian juga sebaliknya terdapat perusahaan-perusahaan yang merasakan penurunan laba yang sangat besar akibat pandemi covid-19 ini. Hal tersebut juga tampak pada nilai minimum dan maksimum pada tabel 3 di atas.

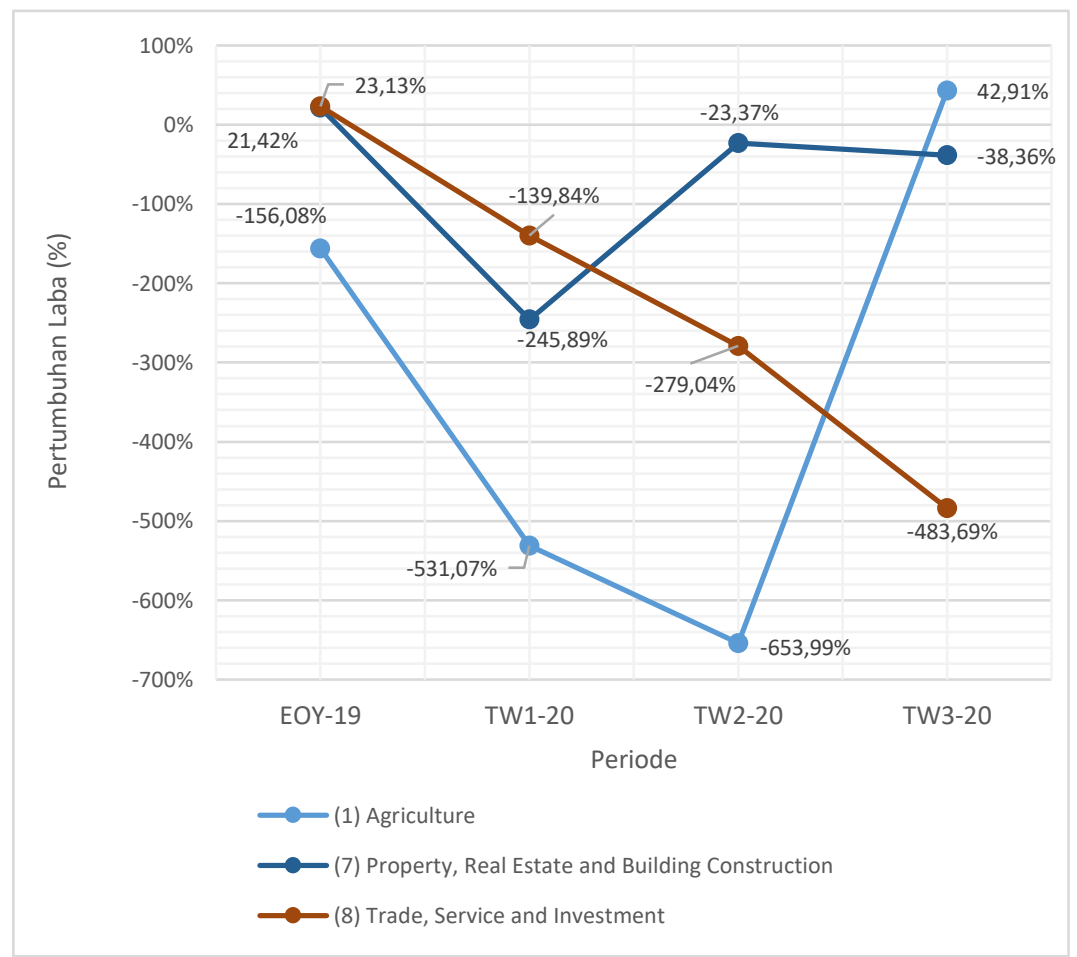

Gambar 5. Grafik pertumbuhan laba sektor (1)Agriculture, (7)Property, Real Estate and Building Construction, dan (8)Trade, Service and Investment

Sektor industri yang mengalami dampak perubahan tingkat laba dari adanya kondisi Covid-19 dibagi menjadi terdampak berat, terdampak sedang dan terdampak ringan.

\section{Terdampak Berat}

Sektor dengan kategori terdampak berat pada penurunan rata-rata labanya, seperti ditunjukkan pada gambar 5 di atas, mengalami penurunan laba pada TW1 hingga TW 3 tahun 2020 sebesar lebih dari 100\% hingga 650\% antara lain sektor (1) Agriculture, (7) Property, Real Estate and Building Construction, dan (8) Trade, Service and Investment. 


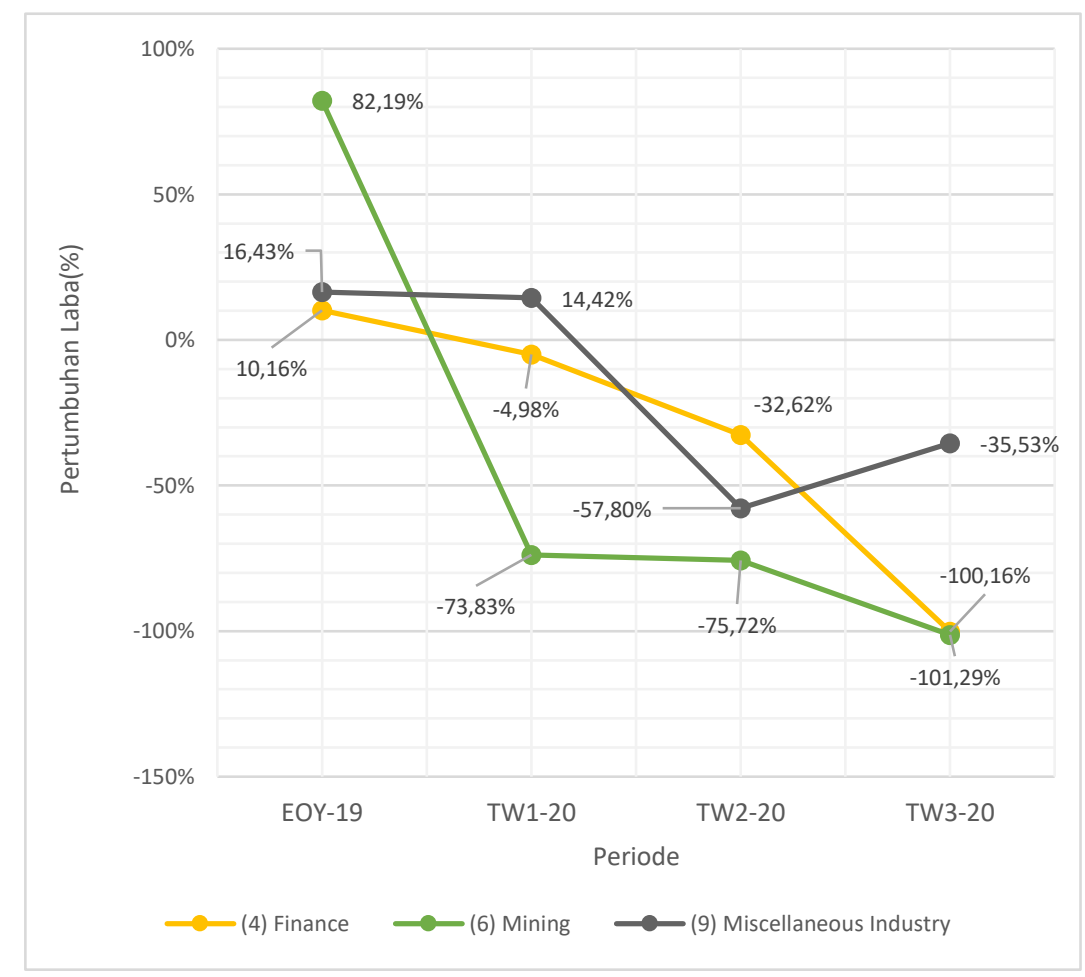

Gambar 6. Grafik pertumbuhan laba sektor (4) Finance, (6) Mining, dan (9) Miscellaneous Industry

\section{Terdampak Sedang}

Sektor yang mengalami dampak kategori sedang akibat terjadinya pandemi Covid-19 mendapatkan penurunan rata-rata laba $4 \%$ hingga $100 \%$ pada TW1 sampai TW3 tahun 2020, seperti ditunjukkan pada gambar 6 antara lain sektor (4)Finance, (6)Mining, dan (9) Miscellaneous Industry.

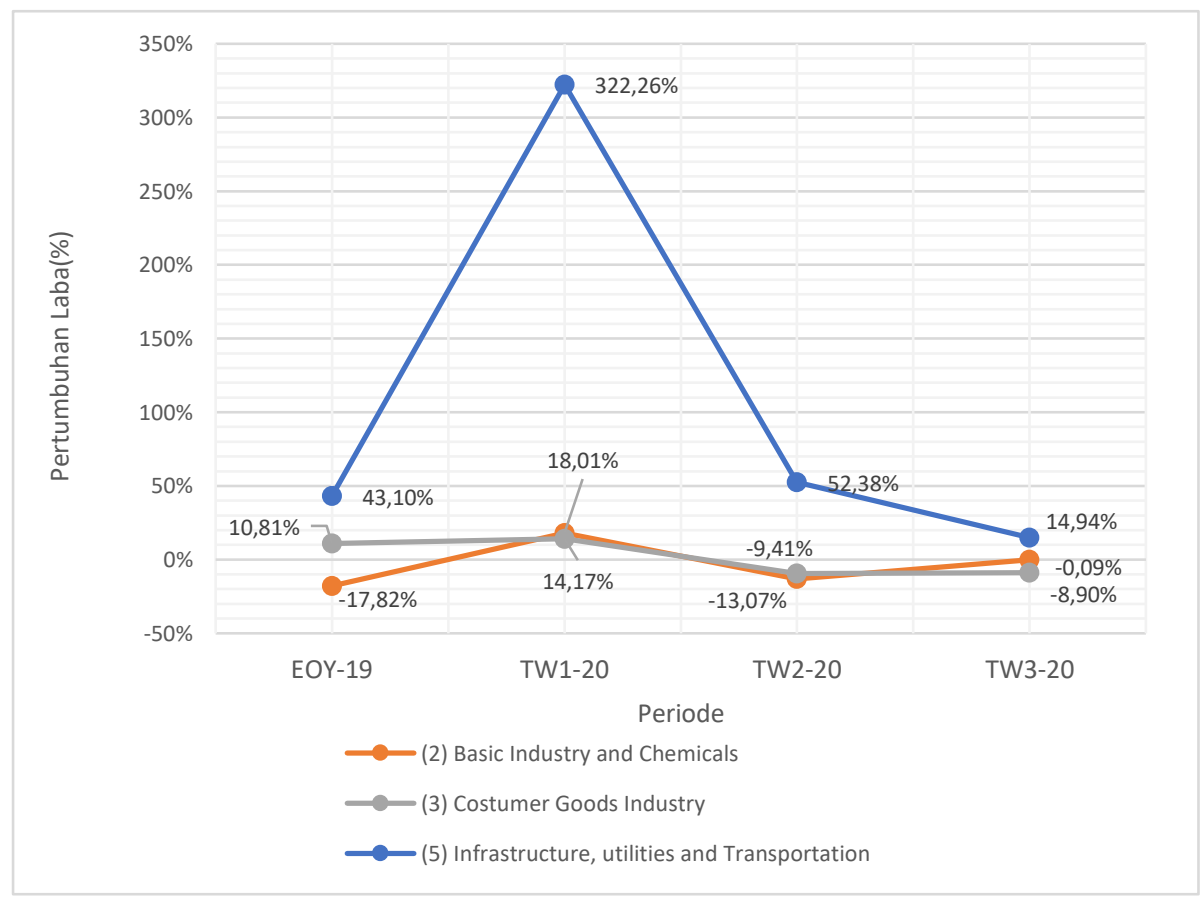




\section{Gambar 7. Grafik pertumbuhan laba sektor (2) Basic Industry and Chemicals, (3) Costumer Goods} Industry, (5) Infrastructure, utilities and Transportation

\section{Tidak terdampak / Terdampak Ringan}

Sedangkan sektor yang tidak terdampak dan hanya terdampak ringan pada penurunan rata-rata labanya antara lain sektor Basic Industry and Chemicals, Costumer Goods Industry, dan Infrastructure, utilities and Transportation.

Seperti ditunjukkan pada gambar 7, sektor Infrastructure, utilities and Transportation justru mengalami peningkatan laba pada TW1 - TW 32020 sebesar 322,26\%, 52,28\%, dan 14,94\%, meskipun tingkat penjualannya juga mengalami sedikit penurunan pada TW 2 dan TW3 2020. Namun demikian nilai standar deviasi dan rentang maximum-minimum dari perubahan laba yang cukup lebar menunjukkan variasi yang cukup besar diantara perusahaan-perusahaan yang diambil sampel tersebut. Dengan adanya peningkatan laba tersebut menunjukkan bahwa perusahaan berhasil melakukan usahausaha peningkatan efisiensi biayanya.

Demikian pula dengan sektor Basic Industry and Chemicals dan Costumer Goods Industry yang keduanya mengalami penurunan penjualan pada TW1-TW3 berhasil melakukan berbagai upaya efisiensi sehingga hanya sedikit terdampak pada penurunan labanya dibanding dengan sektor-sektor lainnya.

\section{Rasio Lancar}

Data variabel rasio lancar masing-masing sektor industri dapat ditunjukkan pada Tabel 4 berikut ini.

Tabel 4 Rasio Lancar tiap sektor industri.

\begin{tabular}{llllll}
\hline Sektor (*) & EOY-19 & TW1-20 & TW2-20 & TW3-20 \\
\hline (1) & Mean & $172,20 \%$ & $160,90 \%$ & $195,41 \%$ & $187,36 \%$ \\
& std dev & $153,92 \%$ & $146,07 \%$ & $203,59 \%$ & $178,16 \%$ \\
& Min & $10,64 \%$ & $9,42 \%$ & $10,25 \%$ & $10,60 \%$ \\
& Max & $469,68 \%$ & $465,51 \%$ & $658,17 \%$ & $558,01 \%$ \\
& N & 11 & 11 & 11 & 11 \\
\hline (2) & Mean & $158,60 \%$ & $173,04 \%$ & $180,79 \%$ & $173,32 \%$ \\
& std dev & $92,92 \%$ & $96,53 \%$ & $113,60 \%$ & $94,96 \%$ \\
& Min & $27,70 \%$ & $73,61 \%$ & $76,95 \%$ & $52,04 \%$ \\
& Max & $331,21 \%$ & $394,93 \%$ & $453,51 \%$ & $368,41 \%$ \\
& N & 10 & 10 & 10 & 10 \\
\hline (3) & Mean & $369,29 \%$ & $365,48 \%$ & $427,88 \%$ & $383,97 \%$ \\
& std dev & $316,89 \%$ & $288,14 \%$ & $374,65 \%$ & $316,75 \%$ \\
& Min & $65,29 \%$ & $78,36 \%$ & $82,37 \%$ & $76,15 \%$ \\
& Max & $1263,37 \%$ & $1137,67 \%$ & $1413,53 \%$ & $1193,63 \%$ \\
N & 12 & 12 & 12 & 12 \\
\hline (4)** & Mean & - & - & - & - \\
std dev & - & - & - & - \\
Min & - & - & - & - \\
Max & - & - & & - \\
\hline & & & & - & - \\
\hline
\end{tabular}




\begin{tabular}{|c|c|c|c|c|c|}
\hline \multicolumn{2}{|c|}{ Sektor $(*)$} & \multirow{2}{*}{$\begin{array}{l}\text { EOY-19 } \\
-\end{array}$} & \multirow{2}{*}{$\begin{array}{l}\text { TW1-20 } \\
-\end{array}$} & \multirow{2}{*}{$\begin{array}{l}\text { TW2-20 } \\
-\end{array}$} & \multirow{2}{*}{$\begin{array}{l}\text { TW3-20 } \\
-\end{array}$} \\
\hline & $\mathrm{N}$ & & & & \\
\hline \multirow[t]{5}{*}{ (5) } & Mean & $168,50 \%$ & $217,36 \%$ & $219,17 \%$ & $222,87 \%$ \\
\hline & std dev & $226,95 \%$ & $356,60 \%$ & $359,17 \%$ & $363,04 \%$ \\
\hline & Min & $33,56 \%$ & $37,80 \%$ & $35,59 \%$ & $28,17 \%$ \\
\hline & Max & $668,31 \%$ & $1017,89 \%$ & $1019,06 \%$ & $1024,17 \%$ \\
\hline & $\mathrm{N}$ & 7 & 7 & 7 & 7 \\
\hline \multirow[t]{5}{*}{ (6) } & Mean & $165,70 \%$ & $183,75 \%$ & $178,32 \%$ & $181,27 \%$ \\
\hline & std dev & $60,05 \%$ & $62,66 \%$ & $59,41 \%$ & $50,34 \%$ \\
\hline & Min & $80,59 \%$ & $82,26 \%$ & $83,74 \%$ & $121,28 \%$ \\
\hline & Max & $248,97 \%$ & $275,27 \%$ & $300,54 \%$ & $279,53 \%$ \\
\hline & $\mathrm{N}$ & 10 & 10 & 10 & 10 \\
\hline \multirow[t]{5}{*}{ (7) } & Mean & $221,31 \%$ & $203,24 \%$ & $172,21 \%$ & $165,11 \%$ \\
\hline & std dev & $181,31 \%$ & $149,70 \%$ & $116,12 \%$ & $107,58 \%$ \\
\hline & Min & $32,18 \%$ & $34,84 \%$ & $29,33 \%$ & $28,08 \%$ \\
\hline & Max & $540,56 \%$ & $423,04 \%$ & $371,15 \%$ & $348,42 \%$ \\
\hline & $\mathrm{N}$ & 7 & 7 & 7 & 7 \\
\hline \multirow[t]{5}{*}{ (8) } & Mean & $436,47 \%$ & $381,31 \%$ & $359,08 \%$ & $374,23 \%$ \\
\hline & std dev & $456,40 \%$ & $367,13 \%$ & $313,03 \%$ & $298,59 \%$ \\
\hline & Min & $112,27 \%$ & $98,35 \%$ & $85,52 \%$ & $81,08 \%$ \\
\hline & Max & $1650,70 \%$ & $1349,01 \%$ & $1135,27 \%$ & $1022,44 \%$ \\
\hline & $\mathrm{N}$ & 11 & 11 & 11 & 11 \\
\hline \multirow[t]{5}{*}{ (9) } & Mean & $230,28 \%$ & $240,12 \%$ & $226,08 \%$ & $233,88 \%$ \\
\hline & std dev & $158,28 \%$ & $146,88 \%$ & $175,95 \%$ & $188,19 \%$ \\
\hline & Min & $60,94 \%$ & $69,21 \%$ & $51,69 \%$ & $58,74 \%$ \\
\hline & Max & $490,17 \%$ & $502,30 \%$ & $541,71 \%$ & $627,20 \%$ \\
\hline & $\mathrm{N}$ & 8 & 8 & 8 & 8 \\
\hline \multirow[t]{5}{*}{ (10) } & Mean & $212,62 \%$ & $210,67 \%$ & $219,18 \%$ & $213,60 \%$ \\
\hline & std dev & $258,49 \%$ & $238,31 \%$ & $253,88 \%$ & $234,02 \%$ \\
\hline & Min & $0,00 \%$ & $0,00 \%$ & $0,00 \%$ & $0,00 \%$ \\
\hline & Max & $1650,70 \%$ & $1349,01 \%$ & $1413,53 \%$ & $1193,63 \%$ \\
\hline & $\mathrm{N}$ & 87 & 87 & 87 & 87 \\
\hline
\end{tabular}

(*) Keterangan Sektor (1) Agriculture, (2) Basic Industry and Chemicals, (3) Costumer Goods Industry, (4) Finance, (5) Infrastructure, utilities and Transportation, (6) Mining, (7) Property, Real Estate and Building Construction (8) Trade, Service and Investment, (9) Miscellaneous Industry). (10)Resume data semua sampel yang diambil untuk semua kategori sektor industri. (**) Rasio lancar tidak digunakan pada sektor perbankan

Rasio lancar (current ratio) merupakan salah satu rasio likuiditas yang paling umum dan sering digunakan. Semakin tinggi rasio lancar, maka semakin besar kemampuan perusahaan untuk membayar tagihan jangka pendeknya dengan menggunakan aset lancar. Dari data tersebut di atas pada Tabel 4 dan grafik pada Gambar 8 di atas, terlihat bahwa tidak terdapat perubahan rasio lancar yang signifikan yang mengindikasikan perusahaan tidak mampu memenuhi kewajiban jangka pendeknya sebagai akibat adanya pandemik Covid-19. Dengan rasio lancar lebih besar dari 100\% menunjukkan kemampuan perusahaan dalam memenuhi kewajiban lancarnya hampir sama dengan periode sebelum terjadinya Covid-19. 


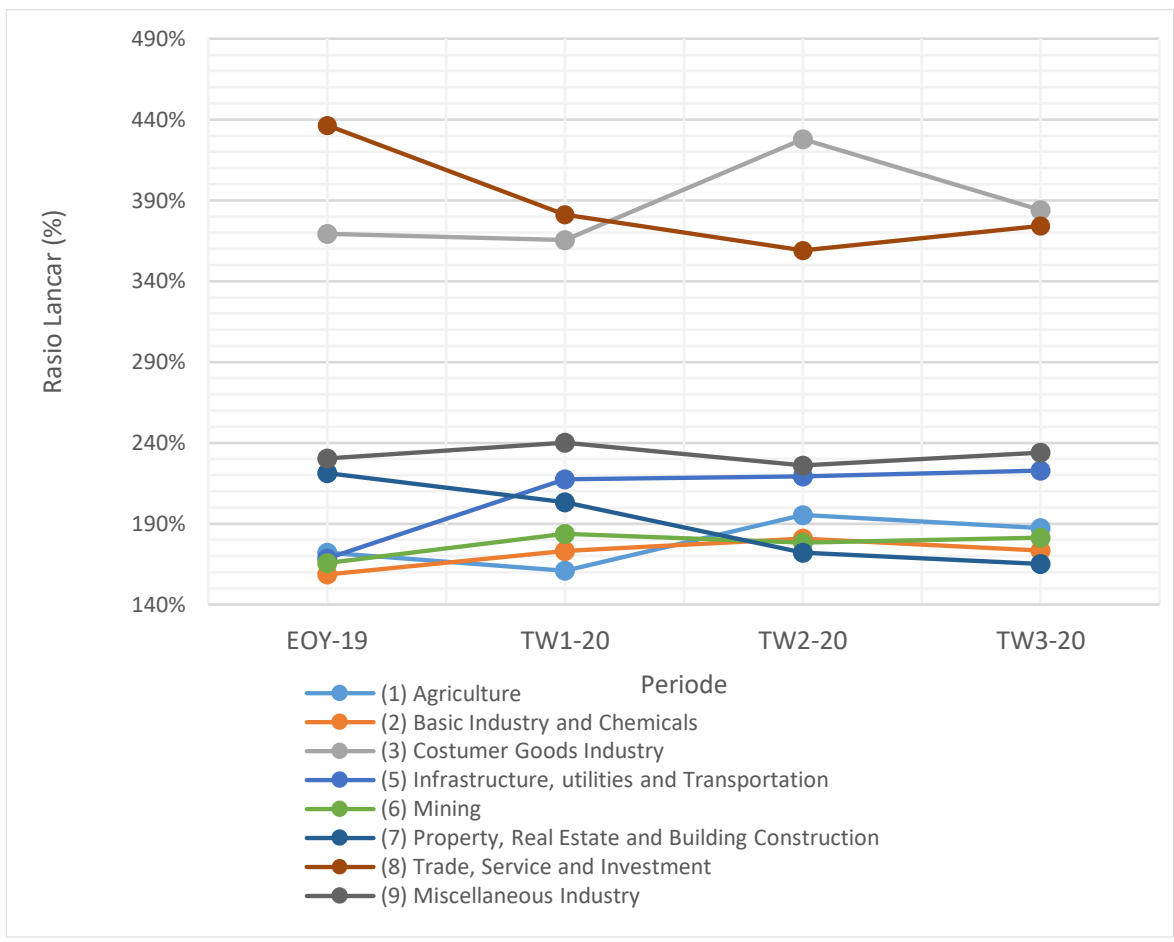

Gambar 8. Trend Perubahan Rasio Lancar

Sumber:analisa data penulis

\section{KESIMPULAN DAN SARAN}

Kesimpulan dari penulisan paper ini adalah:

1. Adanya Covid-19 mengakibatkan turunnya rata-rata penjualan hampir semua sektor industri, yang mulai terlihat pada kuartal 1 hingga kuartal 3 tahun 2020. Namun demikian terdapat sektor yang justru mengalami kenaikan penjualan yakni Agriculture dan sektor Property, Real Estate and Building Construction.

2. Sektor industri yang mengalami tingkat dampak penurunan pendapatan pada 3 peringkat terbesar antara lain sektor (a) Miscellaneous Industry, (b) Basic Industry and Chemicals, dan (c) Mining, mengalami penurunan penjualan lebih dari $10 \%$ hingga $22 \%$.

3. Terjadinya pandemi Covid-19 juga mengakibatkan penurunan rata-rata laba dibandingkan periode yang sama tahun sebelumnya. Besarnya laba perusahaan pada kuartal 1 hingga kuartal 3 tahun 2020 mengalami penurunan yang sangat besar berturut-turut sebesar 87,51\%, 140,99\%, dan $91,00 \%$ dibanding periode yang sama tahun sebelumnya.

4. Sektor yang terdampak besar dari sisi penurunan rata-rata laba pada TW1 hingga TW 3 tahun 2020 sebesar lebih dari 100\% hingga 650\% antara lain sektor Agriculture; Property, Real Estate and Building Construction, dan (8) Trade, Service and Investment. 
5. Tidak terdapat perubahan rasio lancar yang cukup signifikan sebagai akibat adanya pandemik Covid-19

Saran dari penulisan paper ini adalah:

1. Adanya perhatian dari stakeholders pada industri-industri yang mengalami dampak sigifikan akibat pengaruh Covid-19, sehingga dapat dikaji untuk mendapatkan treatment dan stimulasi yang tepat, agar dapat menaikkan perekonomian nasional. 


\section{DAFTAR PUSTAKA}

CAS-FEB-UNPAD. (2020). Dampak Pandemi Corona Terhadap Laporan Keuangan dan Praktik Bisnis di Indonesia. Retrieved 10 29, 2020, from FEB UNPAD: https://feb.unpad.ac.id/dampakpandemi-corona-terhadap-laporan-keuangan-dan-praktik-bisnis-di-indonesia/

IDX. (2020, 10 19). Perusahaan Tercatat: Laporan Keuangan dan Tahunan. Retrieved 10 19, 2020, from Bursa Efek Indonesia: https://www.idx.co.id/perusahaan-tercatat/laporan-keuangan-dantahunan/

Koster, O., \& Igoe, S. (2020). Perspectives: How Covid-19 infects financial reporting and results $\begin{array}{llllll}\text { presentations. } & \text { Retrieved } & 10 & 9 & \text { 2020, from }\end{array}$ https://www2.deloitte.com/ch/en/pages/audit/articles/financial-reporting-survey-q1-2020.html

Satgas Covid-19, S. T.-1. (n.d.). Peta Sebaran. Retrieved 10 19, 2020, from Website Resmi Satuan Tugas Penanganan Covid 19: https://Covid-19.go.id/peta-sebaran

Shen, H. \&. (2020). The Impact of the Covid-19 Pandemik on Firm Performance. Emerging Markets Finance and Trade 56. 2213-2230. 10.1080/1540496X.2020.1785863. , 56.

Van Horne, J. C., \& John M. Wachowicz, Jr. (2009). Financial Statement Analysiss. In Fundamentals of Financial Management,13th Edition (pp. 128-157). Kirby Street, London: Pearson Education Limited. 